\title{
Macroeconomic Determinants of Gender Inequality Index in Eight ASEAN Countries
}

\author{
Joko Sangaji ${ }^{12 *}$, Miyasto $^{2}$, Akhmad Syakir Kurnia $^{2}$ \\ ${ }^{1}$ Kwik Kian Gie Institute of Business and Informatics, Jakarta, Indonesia \\ ${ }^{2}$ Faculty of Economics and Business, Universitas Diponegoro, Semarang, Central Java, Indonesia
}

\begin{abstract}
Gender inequality is a situation where women and men are not equal and it leads to an unequal treatment or an individual perception as a whole. Gender inequality is still a major obstacle to human development. It will have a negative impact on the development of their ability and freedom of choice. This study is aimed to examine macroeconomic determinants, namely gross domestic product per capita, trade and foreign direct investment to gender inequality index in eight ASEAN countries. They are Cambodia, Indonesia, Lao PDR, Malaysia, Myanmar, Singapore, Thailand, and Vietnam. The research was taken from 2010 to 2015 by using the dynamic panel data. The results concluded that all independent variables were significant and had a negative direction. It means that the increase in gross domestic product per capita, trade, and foreign direct investment substantially lowered the gender inequality index in eight ASEAN countries. These results emphasize the importance of continuously improving all macroeconomic determinants because they will impact the decline of gender inequality in eight ASEAN countries.
\end{abstract}

Keywords: Gender Inequality Index; Per Capita Gross Domestic Product; Trade; Foreign Direct Investment; Dynamic Panel Data

\section{Introduction}

Gender inequality remains a challenge for every country in the midst of ever-increasing economic development. The government of each country, of course, continues to work to reduce gender inequalities with varying outcomes. The realization of gender inequality is generally in the areas of education, wages, health, and others. If this continuously occurs, then this will result in the decline of human development. Gender inequality has also gained much attention from researchers from different perspectives, one of them from macroeconomic variables aspects. Ngai, L. Rachel and Petrongolo examine the role of the service sector to narrow the gender gap in the United States[1]. The variables which are studied are market work, wages, and time use. The period which was used was 1968-2008 for the first two variables, and 19652008 for the last variable. The results show that the increase in the services sector contributed 44 percent to the increase in the female market hours and 11 percent to the decline of men.

\section{Methodology}

This research takes samples of 8 ASEAN countries, namely Cambodia, Indonesia, Laos PDR, Malaysia, Myanmar, Singapore, Thailand, and Vietnam. Its period is from 2010 to 2015 . Two ASEAN countries namely Brunei Darussalam and Philippines, are not included in the samples because their gender inequality index data are not complete. This research uses dependent and dependent variables. Dependent variable is Gender Inequality Index (GII). GII is an index published in the Human Development Report, published by the United Nations Development Program (UNDP) since 1990. GII measures three aspects of gender inequality: reproductive health, empowerment, and labor market[2]. Reproductive health is measured by maternal mortality ratio and adolescent birth rates. Empowerment is measured by proportion of parliamentary seats occupied by females and proportion of adult females and males aged 25 years and older Gross Domestic Product (GDP) per capita with at least some secondary

*Corresponding author: jokosangaji2015@gmail.com 
education. Labor market is measured by labour force participation rate of female and male populations aged 15 years and older.

The three independent variables are GDP per capita based on Purchasing Power Parity (PPP), trade and foreign direct investment. GDP per capita based on PPP is GDP per capita converted to international dollars using PPP rates. An international dollar has the same purchasing power over GDP that a U.S. dollar has in the United States. Data are current international dollars based on the 2011 International Comparation Program round population[3]. Trade is the sum of exports and imports of goods and services measured as a share of gross domestic product[4]. Foreign direct investment are the net inflows (new investment inflows less disinvestment) in the reporting economy from foreign investors, and is divided by GDP [5].

The data are analysed using descriptive statistics and dynamic panel data. Descriptive statistics include mean, maximum, minimum, range, and standard deviation values. The dynamic panel data is displayed after the publication of Arellano and Bond[6]. The dynamic panel data model includes the lag of the dependent variable as regressor in the regression model.

Here is a dynamic model form:

$$
y_{i t}=\delta y_{i, t-1}+x^{\prime}{ }_{i t} \beta+u_{i t}, \quad i=1, \ldots, N ; t=1,
$$$$
\ldots, T
$$

where $\delta$ is a scalar, $\mathrm{x}^{\prime}$ it is $1 \times \mathrm{K}$ and $\beta$ is $\mathrm{K} \times 1$. In this case, $u_{i t}$ is assumed to follow the one way error component model as follows:

$$
u_{i t}=\mu_{i}+v_{i t}
$$

where $\mu \mathrm{i} \sim \operatorname{IID}\left(0, \sigma_{\mu}^{2}\right)$ is the individual influence and vit $\sim \operatorname{IID}\left(0, \sigma_{v}^{2}\right)$ is transient error.

If the model (2) is estimated with fixed effects or random effects approach, it will result in biased and inconsistent estimators. To solve this problem, Arellano and Bond (1991) proposed the method of moments approach or commonly called Generalized Method of Moments (GMM). There are two commonly used estimation procedures within the GMM framework to accommodate the above issues: First-Differences GMM (FD-GMM) and System GMM (SYS-GMM).

FD-GMM uses the first difference equation. This transformation will eliminate $\mu_{\mathrm{i}}$ and allow endogenous lag variables in the second and previous periods to be the right instrument variables as long as there is no serial correlation in random error. It can be tested by using serial correlation test for residual in the form of first difference. There are limitations of the FD-GMM estimator, especially if there is a correlation between the lags of the first differentiator, so the instruments used are weak[7]. The FD-GMM estimator will be even more biased down than fixed-effects, especially when the number of time periods is limited. Therefore, the use of both the present and lag values of the regressor as an instrument will improve the FD-GMM estimator.

GMM system method is developed with the basic idea to estimate the equations system either on firstdifference or on level[7]. At the level estimate, the first-difference lag was used as the instrument. The use of lag from a series of levels provides weak instruments for first differenced in large $\mathrm{N}$ and relatively small $\mathrm{T}$ cases[7]. Therefore, the suggestion of two alternative estimators that requires the restriction of the initial conditions designed to improve the properties of the first-differenced GMM estimator[7], that is: (1) The first type of restriction uses the extended linear GMM estimator which applies the $y_{\text {it }}$ difference lag as an instrument for the equation level, in addition to the lag $y_{i t}$ level used as an instrument for the first difference equation; and (2) The second type of restriction validates the use of the GLS error component estimator on an extended model conditioned on observed initial values. This restriction provides a consistent estimator under homoscedastic, normal assumptions, which are asymptotically equivalent with conditional maximum likelihood.

\section{Discussion}

Foreign Direct Investment affects employment conditions in a country. Higher wages and better employment opportunities for workers in foreign companies in a country will change the relative price of inputs, and will then affect different groups. Foreign Direct Investment can change individual preferences, how to view new ways of employment and workers' rights, and reduce discrimination[8]. Gender inequality has also received the attention of many researchers. The following research results are examining if economic growth, trade, and foreign direct investment affect gender inequality. The income elasticity of investments in the number of children is smaller than the number of children's education[9]. Therefore, the increase in income will decrease fertility. At the macroeconomic level, fertility decline will allow women to enter the labor market, thus reducing the gender gap in labor force participation.

Foreign Direct Investment (FDI) inflows significantly increases environmental degradation; hence causing a negative impact on sustainable environment. It was found that institutions and governance strongly moderate harmful effect of this relationship whilst host country specific interventions also impact the eco-system in host countries.

The differences between men and women in employment, wages or poverty are primarily due to differences in human capital. These differences are the result of traditional structures that tend to disappear over time. Some of the gender gaps in wages or jobs can actually be linked to 
discrimination. The process of economic growth and market competition decrease the discrimination. The economic growth can positively affect gender equality[10]. Technological advances encourage the introduction of durable goods that save labor. Changes in technology of capital goods decrease the relative price of household durable goods and increase the adoption of modern equipment. In turn, the adoption reduces the amount of time for women to complete household work and increases the participation of the their labor force.

Foreign Direct Investment has a positive nonlinear relationship to inter-industrial wage differentials. The results of the research are presented in 2 ways, namely the results of descriptive and dynamic panel data. The results of the descriptive statistics for the values of the mean, maximum, minimum, range, and standard deviation for the whole country are presented in Table I. The results of the dynamic panel data are presented in Table II. Table I presented by descriptive statistics of each variable on the eight ASEAN countries, Gender Inequality Index had a mean of 0.37 , a range of 0.44 , and a standard deviation of 0.13 . GDP per capita had a mean of 17,615.76, a range of 78.369.13, and a standard deviation of 23,649.93. Trade as a share of gross domestic product had a mean of 135.25 , a range of 379.41 , and a standard deviation of 99.16. Foreign Direct Investment, net inflow as a share of Gross Domestic Product had a mean of 6.62 , a range of 24,01 , and a standard deviation of 6.20. Of the four variables, the highest values for mean, range, and standard deviation are GDP per capita and lowest is Gender Inequality Index. In the next discussion, factors that affect the Gender Inequality Index in eight ASEAN member countries will be analysed. Data are analysed using dynamic panel data with System-Generalized Method of Moment (SYS-GMM).

The results of dynamic panel model presents the estimation results of coefficients of factors affecting the Gender Inequality Index, test for AR (1) errors, test for AR (2) errors, Sargan over-identification test, and Wald (joint) test. The test for AR (1) errors resulted $\mathrm{z}$ value $=-1.5223$ and the test for AR (2) errors resulted value $\mathrm{z}=0.6646$ and both are not significant at $\alpha$ of $5 \%$. In theory, the value of AR (1) is significant. The result of AR (1) is incompatible with the theory because AR (1) is insignificant. Furthermore, the statistical value of the Sargan test is 5,182 and not significant at $\alpha$ of $5 \%$. This shows that there is no correlation between residue and overidentifying restrictions, so it can be said that the instrument is valid. The results of Wald (joint) test amounted to 4667.92 and significant at $\alpha=5 \%$. This shows that in the model there is a relationship between independent and dependent variables.

The regression coefficient of Gender Inequality Index lag 1 (1_GDP (-1)) is 0.4817 and significant at $\alpha$ of $5 \%$. This shows that the Gender Inequality
Index of lag 1 has a sufficient evidence to positively affect the Gender Inequality Index. If the Gender Inequality Index of lag 1 rises 1 percent, then the Gender Inequality Index rises by 0.4817 .

The regression coefficient of GDP per capita based on PPP in 2011 is -0.0568 and significant at $\alpha$ of $10 \%$. This shows that GDP per capita is sufficiently evident to negatively affect Gender Inequality Index. If the GDP per capita is up 1 percent, then the Gender Inequality Index will fall by 0.0568 .

The regression coefficient of trade as the share of Gross Domestic product (1_Trade_GDP) is 0.0081 and is significant at $\alpha$ of $5 \%$. This shows that trade as a share of GDP is proven to negatively affect Gender Inequality Index. If trade as a share of GDP Gross Domestic Product rises 1 percent, the Gender Inequality Index decreases by 0.0081 . The regression coefficient from Foreign Direct Investment, net inflows, as the share of Gross Domestic Product is -0.0421 and significant at $\alpha$ of $10 \%$. This shows that Foreign Direct Investment, net inflows, as a share of Gross Domestic Product is proven to negatively affect Gender Inequality Index. If Foreign Direct Investment, net inflows, as a share of Gross Domestic Product rose by 1 percent, the Gender Inequality Index decreased by 0.0421.If put in order from the highest to the lowest regression coefficient (Table II), Gender Inequality Index lag 1 has the highest regression coefficient. This variable emerges because this model uses the dynamic panel data from Arellano and Bond[6] and Bond and Bundell[7]. Moreover, the second, third and fourth are Gross Domestic Product per capita, Foreign Direct Investment and Trade respectively.

The result concluding that Gross Domestic Product per capita, Trade, dan Foreign Direct Investment negatively influence Gender Inequality Index is in line with the studies by Ngai and Petrongolo[1], Oostendorp[12], and Greenwood, Seshadri, and Yorukoglu[11].

The result means that the government in eight ASEAN countries have to take some measures to improve Gross Domestic Product per capita, Trade, dan Foreign Direct Investment. It is essential because it will decrease gender inequality. The improvement of Gross Domestic Product per capita has to consider each sector contribution in forming Gross Domestic Product so as to determine which sector will be the priority. Trade in eight ASEAN countries needs improving through competitiveness improvement. Similarly, Foreign Direct Investment should also be enhanced by improving the investment climate in each countries. 


\section{Conclusion}

The conclusion of this research is Gross Domestic Product per capita is sufficiently evident to negatively affect Gender Inequality Index; Trade as a share of Gross Domestic product is proven to negatively affect Gender Inequality Index; and Foreign Direct Investment, net inflows, as a share of Gross Domestic Product is proven to negatively affect Gender Inequality Index. This finding implies that the eight ASEAN countries should take some measures to improve Gross Domestic Product per capita, Trade, and Foreign Direct Investment so as to prevent Gender inequality.

\section{References and Notes}

1. L. R. Ngai and B. Petrongolo, Gender Gaps and the Rise of the Service Economy, American Economic Journal: Macroeconomics Vol. 9, No. 4:1-44 (2017).

2. The United Nations Development Programme, Human Development Report 2016: Human Development for Everyone, New York, The United Nations Development Programme (2016).

3. World Bank, GDP per capita, PPP (current international \$), Retrieved from http://data.worldbank.org on October 16, 2017 (2017).

4. World Bank, Trade (\% GDP), Retrieved from http://data.worldbank.org on October 16, 2017 (2017).
5. World Bank, Foreign direct investment, net inflows (\% of GDP), Retrieved from http://data.worldbank.org on October 16, 2017 (2017).

6. M. Arellano and S. Bond, Some Tests of Specification for Panel Data: Monte Carlo Evidence and an Application to Employment Equations, Review of Economic Studies, Vol. 58, Issue 2: 277-297 (1991).

7. R. Blundell and S. Bond, Initial conditions and moment restrictions in dynamic panel data models, J.Eco., Vol. 87: 115-143 (1998).

8. E. Aguayo-Téllez, The Impact of Trade Liberalization Policies and FDI on Gender Inequalities. A Literature Review, Background paper for the World Development Report 2012 (2011).

9. Gary S. Becker and H. Gregg Lewis, On the Interaction between the Quantity and Quality of Children, J.Pol.Eco. , Vol. 81, No. 2: S279S288 (1973)

10. N. Forsythe et al., Gender Inequalities and Economic Growth: A Longitudinal Evaluation, Economic Development and Cultural Change, Vol. 48, No. 3: 573-617. (2000).

11. J. Greenwood et al., Engines of Liberation, Review of Economic Studies 72: 109-133 (2005).

12. R. H. Oostendorp, Globalization and the Gender Wage Gap, The World Bank Economic Review, Vol. 23, No.1: 141-161 (2009). 